\title{
BRAND DAN DIGITAL DALAM ASPEK PERANCANGAN ARSITEKTUR
}

\author{
Onie Dian Sanitha ${ }^{1 *}$, L.M.F. Purwanto ${ }^{1}$ \\ 1.Program Studi Doktor Arsitektur, Fakultas Arsitektur dan Desain, Universitas Soegijapranata, Semarang \\ *Correspondent Author: \\ Tgl masuk naskah: 12-06-2021 • Tgl review I: 17 \& 22-07-2021 • Tgl revisi: 04-08-2021• Tgl review II: 08-08-2021
}

Tgl terbit 06-09-2021

DOI: $10.24167 /$ joda.v1i1.3377

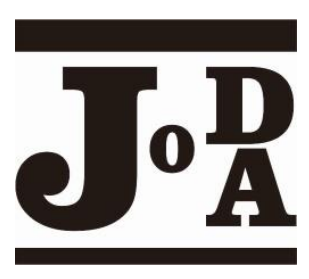

\begin{abstract}
Abstrak: Sebagai bidang ilmu seni terapan, Teori Arsitektur berkembang tidak hanya kepada desain perancangan bangunan saja melainkan isu lingkungan sosial yang berkolaborasi dengan disiplin ilmu Manajemen yakni brand dan konsep "branding". Tuntutan pasar Global menjadikan Arsitektur sebagai sebuah kebutuhan karena kemampuannya dalam menuangkan gagasan ke dalam sebuah bentuk serta perkembangannya di bidang Digital. Hal ini membuat arsitektur mampu membaur dengan disiplin ilmu Manajemen dalam konteks Brand. Namun muncul pertanyaan, apakah konsep perancangan Arsitektur mampu mewadahi sebuah Brand tanpa kehilangan esensi dasar dalam mendesain? Artikel ini menjadi tahap awal dalam melihat keterkaitan antara Arsitektur, kemajuan Teknologi Digital dan konsep Brand. Studi Kepustakaan diperlukan untuk mengawali proses identifikasi agar dapat menguraikan masingmasing bagian sehingga ditemukan aspek-aspek penting yang diperlukan dalam perancangan yang diduga saling berkaitan dan dapat menjadi konsep perancangan yang mendukung proses branding.
\end{abstract}

Kata Kunci: Brand, Branding, Perancangan Arsitektur, Digital, Ilmu Manajemen

\begin{abstract}
As a field of applied art, Architectural Theory develops not only about building design but also about social environmental issues which in collaboration with Management disciplines called brand and branding concept. Global market demands make Architecture as a necessity because of its ability to put ideas into a form and its development in the Digital field. It makes architecture able to blend with the discipline of Management in Brand context. However, the question arises, is the concept of architectural design able to accommodate a brand without losing the basic essence of designing? This article become the first step for looking at the relationship between Architecture, the advancement of Digital Technology and the Brand concept. Literature study is needed to start the identification process in order to describe each part which is found important in aspects to design that are thought to be interrelated and become a design concept that supports the branding process.
\end{abstract}

Keywords: Brand, Branding, Architectural Design, Digital, Management Science

\section{PROLOG}

Pada awal abad 21, pemanfaatan media digital dalam konteks bisnis berkembang pesat. Perkembangan ini memicu setiap disiplin ilmu untuk berkolaborasi satu dengan lain. Misal, Digital Media (DM) dengan Data Science (DS) yang membentuk sebuah ekosistem digital yang mengutamakan pengguna sebagai aspek penting sehingga menghasilkan temuan untuk memahami kebutuhan pengguna dengan mempelajari kebiasaan pengguna ketika mengoperasikan produk digital milik pribadinya [1]. Tanpa sadar dunia maya saat ini sudah merasuk dalam kehidupan sehari-hari di setiap komponen dan kesempatan yang ada. Hal ini membuat kita harus mampu hidup berdampingan dengan teknologi berbasis internet dengan segala kecanggihan di dalamnya. Demikian pula dalam arsitektur, sulit mengesampingkan digital dalam ranah arsitektur. 
Di lain hal, Arsitektur sebagai ilmu seni terapan memiliki parameter, esensi, dan propertinya sendiri dengan banyak ketentuan untuk memenuhi sebuah standar fungsi. Arsitektur yang awalnya sebagai sebuah "shalter" kini berkembang dengan esensi fungsi yang dilengkapi dengan bentuk, ruang, tatanan [2] kemudian berkembang esensinya menjadi bentuk ruang dan perilaku [3], ada pula pengembangan lainnya seperti bentuk, ruang dan makna. Ha ini menjadikan arsitektur mampu berkolaborasi dengan disiplin ilmu lain.

Arsitektur sebagai ilmu seni terapan memiliki parameter, esensi, dan propertinya sendiri dengan banyak ketentuan untuk memenuhi sebuah standar fungsi. Arsitektur yang awalnya sebagai sebuah "shalter" kini berkembang dengan esensi fungsi yang dilengkapi dengan bentuk, ruang, tatanan [2] kemudian berkembang esensinya menjadi bentuk ruang dan perilaku [3], ada pula pengembangan lainnya seperti bentuk, ruang dan makna. Pengembangan-pengembangan ini selanjutnya menjadikan arsitektur mampu berkolaborasi dengan disiplin ilmu lain.

Sebagaimana arsitektur yang begitu memperhatikan pengguna sebagai aspek desainnya, demikian pula teknologi diciptakan dengan mengutamakan manusia sebagai aspeknya, mempermudah manusia dalam berkarya dan beraktivitas. Dalam sebuah tulisannya tentang "Arsitektur Post-Digital" Spiller (2009) memaparkan pentingnya arsitektur untuk bersinergi dengan berbagai ilmu pengetahuan karena sifat sintesisnya yang aktual biologis sehingga dapat berkolaborasi dengan teknologi untuk melayani kebutuhan manusia [4]. Tulisan ini dibuat untuk melihat komponen-komponen digital apa yang dapat digunakan untuk menjadi bagian dari metode kerangka digital (digital framework) sehingga dapat menghasilkan komponen yang mendukung rancangan dan perencanaan desain arsitektur yang berkelanjutan.

\section{TINJUAN PUSTAKA}

Kegiatan merancang adalah sebuah aktivitas yang menjadi fokus penting dan utama yang memerlukan pemahaman dasar yang dikembangkan dan terhimpun dalam sebuah komposisi teori Arsitektur. Komposisi yang terbentuk di dalam kesatuan teori ini digunakan sebagai acuan dalam aktivitas perancangana arsitektur. Dilihat dari konteksnya, terdapat konteks fisik dan non fisik di dalam kategori teori perancangan arsitektur. Penataan ruang maupun kawasan adalah ungkapan tidak langsung dari wujud non fisik seperti tatanan sosial dan kebudayaan masyarakat. Kaidah yang diterapkan mampu mengatur bentuk ruang dan masa pada bangunan sesuai dengan kosmologi yang dipatuhi [5] serta hierarki dan kegunaannya. Hal ini cukup banya terlihat pada permukiman tradisional. Secara teori, sebuah penataan secara spasial dimasukan pada tahap perencanaan.

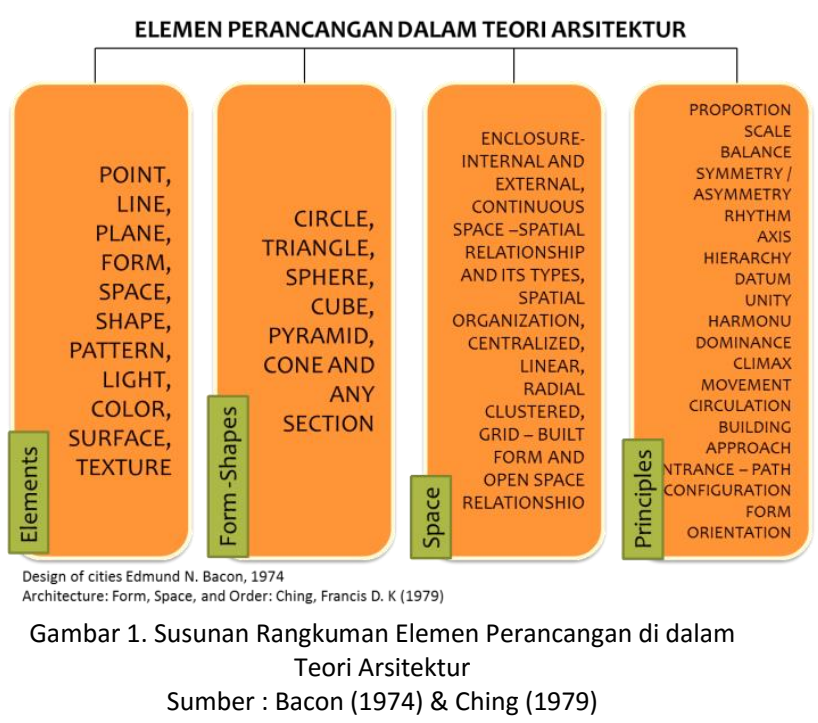

Pada konteks fisik, perilaku pengguna atau penghuni sangat memengaruhi proses desain perancangan yang mampu beradaptasi dan selaras dengan lingkungan, sumber alam dan ekosistem. Aspek non Fisik erat kaitannya dengan tradisi dan peradaban. Selain itu ada aspek seni atau kesenian berifat yang abstrak yang dapat berpengaruh terhadap pengetahuan dan gagasan di keseharian masyarakat. Beberapa sudut pandang yang dapat membawa pengaruh antara lain aktivitas kesibukan pekerjaan (ekonomi), kekerabatan dan organisasi sosial, bahasa, kepercayaan, seni, pernikahan dan IPTEK [5]. Dalam hal seni, acuannya adalah estetika yang muaranya berada pada hasrat dan keindahan, baik yang dapat dinikmati oleh mata maupun telinga serta perwujudan sederhana hingga kompleks. Hasil karya seni dapat dipengaruhi oleh aspek kebudayaan serta perspektif yang sudah dijelaskan sebelumnya. Nilai sosial, budaya, dan sejarah masa lalu (linkage history) bersama dengan individu-individu yang tinggal di dalamnya dan saling terintegrasi merupakan elemen yang penting dalam memaknai sebuah ruang sehingga menjadi sebuah tempat (place). Setiap tempat (place) mempunyai nilai personalitas dan keunikannya masing-masing yang salah satunya terdapat pada desain sebuah 
bangunan dengan karakter material, bentuk, tekstur, warna dan nilai-nilai budaya yang tidak terlihat [6].

\section{KONSEP BRAND}

Brand berhubungan erat dengan sebuah identitas sehingga menjadi landasan kuat dalam pembentukan sebuah produk, personal, maupun karya-karya sebuah perusahaan. Terdapat 4 pilar penting yang perlu diperhatikan ketika ingin membentuk sebuah brand yakni People, Pride, Passion, and Promise [7].

Brand merupakan identitas dari penanda seperti nama, logo, lambang, simbol, kata, atau penanda lainnya yang menyatakan identitas sebuah produk, perusahaan, personal dan semacamnya yang membutuhkan identitas (gambar 1). Untuk dapat memperkenalkan dan mengembangkan sebuah brand diperlukan aktivitas komunikasi yang disebut branding. Identitas yang meliputi struktur genetic, DNA, jiwa, substansi terdalam, dan kualitas yang paling esensial dari produk / perusahaan merupakan hal/karakter/elemen yang mampu membentuk identitas sebuah brand [8].

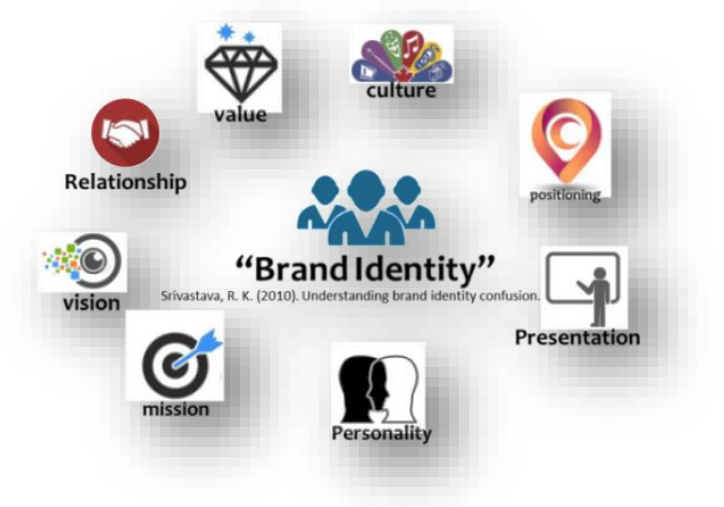

Gambar 2 Komponen Pembentuk Brand Sumber Ilustrasi : Peneliti, 2020

Konsep brand perlu dipahami melalui 3 gagasan, pertama brand perlu menawarkan perbedaaan yang unik, kedua nilai tambah bagi customer, dan ketiga, brand harus memiliki kemampuan dalam mengekspresikan pengalaman karakteristik brand tersebut [9]. Namun demikian, unsur pembentuk brand pada hakikatnya harus selaras dengan etika sehingga komponen tersebut perlu dimasukan dalam konsep brand. Selain itu pondasi budaya serta estetika akan membantu menciptakan brand yang kuat. Sebuah persepsi estetis terhadap brand akan bergantung pula dari bagaimana identitas dari brand tersebut mampu divisualkan. Terlebih dari semuanya itu, etika adalah hal prinsip yang harus menjadi dasar dalam sebuah brand [10, p. 4].

Konsep brand semakin berkembang melirik sisi sosial masyarakat dalam perilaku konsumtifnya di pasar sehingga memunculkan gagasan bahwa aktivitas pemasaran lebih dari sekedar kegiatan jual beli saja melainkan mampu menciptakan sebuah sistem sosial baru. Hal ini menjadi inspirasi dalam membentuk konsep branding untuk menaruh fokus perancangannya kepada pengguna dengan menghimpun data pelanggan untuk menentukan produk apa yang dibutuhkan dan digunakan pelanggannya di dalam sistem kehidupan sosial mereka [11].

Dalam konsep brand Kotler mengungkapkan bahwa disiplin ilmu manajemen pemasaran terus berkembang, dan setidaknya selama 40 tahun terakhir dan sudah banyak mengalami penyesuaian, media pemasaran yang tadinya dilakukan secara langsung, kini berkembang menjadi media tidak langsung sebagai bentuk komunikasi tambahan yang baru. Etika serta implikasi dari sistem sosial juga turut memengaruhi pengembangan teknik ilmu brand sehingga orientasi perusahaan saat ini terletak pada pelanggan atau pengguna. Hal ini sejalan dengan terknologi digital yang mulai bertransformasi kearah penggunanya dan menjadikan data pengguna sebagai dasar pengembangannya.

\section{BRANDSCAPE}

Brandscaping merupakan sebuah pemetaan tentang persepsi konsumen atas sebuah simbol atau produk yang disediakan oleh sebuah merek tertentu. Pemetaan persepsi konsumen tersebut menjadi landasan bagi para pelaku manajerial brand untuk mencari cara dalam memaksimalkan nilai sebuah produk sehingga dapat berkembang dan dikenal oleh banyak orang. Brandscaping dipahami sebagai perpaduan antara "Brand" dan "Landscape". Brandscape ini menjadi panduan bagaimana kegiatan branding dapat dikembangkan. Brandscaping dalam hal media dapat dilihat dari fenomena kemitraan dan ekspasi layaknya franchise. Brandscaping dalam hal selebriti berkaitan dengan aktivitas endorsement. Sementara dilihat dari keterkaitannya dengan desain arsitektur, brandscaping diwujudkan melalui desain yang representatif serta konsisten dengan produk atau nilai-nilai perusahaan sehingga karya arsitektural mampu berkontribusi dalam membentukan identitas sebuah merek [12]. 


\section{KONSEP DIGITAL DALAM ASPEK PERANCANGAN ARSITEKTUR DAN BRAND}

Dalam hal bisnis, konsep digital merupakan sebuah upaya yang dikembangkan dengan memasukkan teknologi informasi sebagai cara untuk menemukan sebuah kesempatan bisnis, inovasi serta jalan untuk dapat terus berkembang. Konsep Digital saat ini sudah bertransformasi membantu kita dalam mengidentifikasi model bisnis dengan komponen pembentuk seperti strategi, proses, kemampuan [13], pengalaman [13], budaya [13]dan teknologi menjadi sebuah kekuatan bagi seseorang dalam melakukan dan mencari hal-hal yang menarik sehingga menempatkannya pada posisi vital dalam pembentukan bisnis model [11]. Terdapat beberapa komponen dalam konsep Digital yang dirangkum dari berbagai sumber menurut konteks Arsitektur dan Brand, yakni terbagi atas 3 hal berikut.

a) Konteks Teknologi sebagai Komponen Pendukung Desain

Komponen penting dalam hal teknologi meliputi kecerdasan buatan, media data seperti cloud, perlindungan secara virtual atau cyber security, perangkat yang digunakan dan interkoneksi dan otomatisasi yang tergabung dalam Internet of Things [14]

b) Konteks Data sebagai Sumber Informasi

Dalam hal penyediaan data terdapat beberapa tipe sumber data, yakni tipe data transaksional dan non transaksional, data operasional dan sumber data online. Data transaksional ini meliputi informasi alur transaksi, Data non-transaksional berupa perilaku dan lifestyle pengguna. Data operasional meliputi strategi dan kegiatan yang berhubungan dengan bisnis, dan tipe Data online merupakan konten data berbasis pengguna seperti Tweets, likes, search engine, music, transaksi online, email, foto, shares, website, video dII [1]

c) Media Platform sebagai Media Proses atau Analisis

Konsep teknologi digital dapat meluruskan informasi yang bersifat tidak selaras antara penyedia dengan penerima (customer). Melalui media digital online, kita juga mampu membaca perilaku customer. Dengan kemajuan tersebut, diperlukan sebuah platform sebagai media jembatan digital yang menghubungkan penyedia dengan customer dan customer dengan sesama customer. Media platform berbasis digital inilah yang dapat digunakan dalam melakukan analisis "interaksi teknologi " perilaku customer. Platform tersebut dapat berupa media social, search engine, youtube, perdagangan online atau $e$ commerce, berita online atau online news. Selain itu, saluran digital tersebut dapat membantu perusahaan dalam menemukan nilai-nilai apa perlu dikembangkan dalam proses branding agar sesuai dengan tujuan perusahaan dan tepat sampai pada penerima/customer [15].

\section{METODE PEMBAHASAN}

Studi literatur akan menjadi dasar penyusunan artikel ini, pertama akan dijabarkan terlebih dahulu elemen-elemen utama dalam perancangan Arsitektur. Tahap berikutnya mencatat elemenelemen yang memiliki keterkaitan dengan konsep brand dalam teknik perancangan Arsitektur dan teknik branding secara digital.

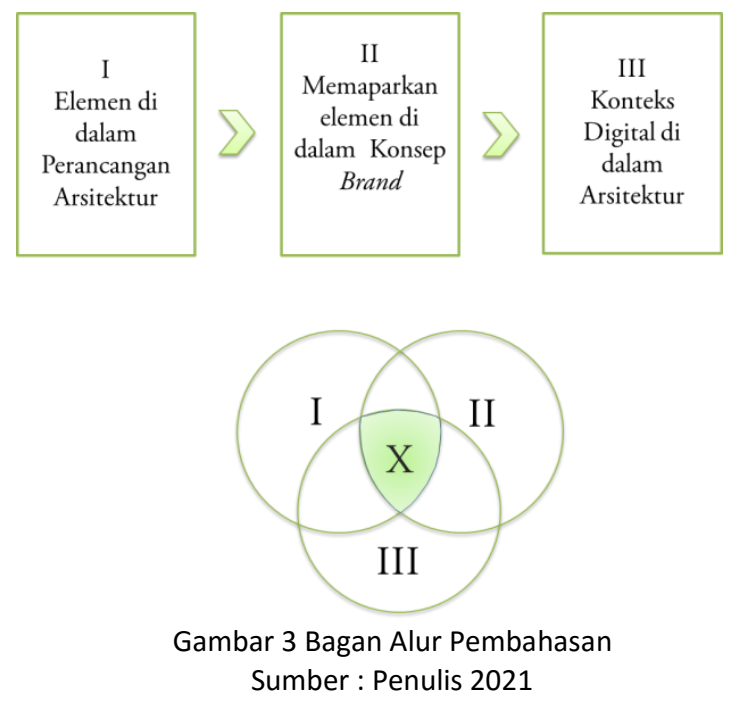

Kemudian mencari irisan dari ketiganya dan menyimpulkan gagasan dari irisan tersebut sebagai pertimbangan pengembangan di dalam aspek perancangan Arsitektur.

\section{PEMBAHASAN}

\section{ASPEK PERANCANGAN DALAM ARSITEKTUR}

Dalam arsitektur, beberapa prinsip yang menjadi pedoman perancangan meliputi : utilitas, firmitas 
dan venustas menurut Vitruvius, dapat pula diterjemahkan pada konsep komoditas, firmness, dan delight dan saat ini prinsip tersebut digunakan untuk mengidentifikasi karya, fungsi dan aspek sintesis sebuah bangunan. Selain itu terdapat pula prinsip perancangan yang digagas oleh Ching berupa bentuk, ruang, dan tatanan dengan prinsip - prinsip penyusunnya (lihat Gambar 2) berupa sumbu, simetri, datum, hierarki, irama, pengulangan dan transformasi [2].

\section{BRAND DI DALAM ARSITEKTUR}

Brand merupakan kesatuan dalam sebuah identitas. Identitas tersebut menjadi landasan yang sangat kuat di dalam proses merancang sebuah karya yang dapat berbentuk produk, personal, serta karya-karya lainnya. Melalui pilar People, Pride, Passion, and Promis sebuah brand membentuk sebuah karya sarat makna. Lalu di mana letak Arsitektur?

Keterkaitan Arsitektur dengan brand paling mudah dilihat dalam konteks bangunan di ruang publik khususnya bangunan komersial. Karya yang ingin diperkenalkan kepada direpresentasikan melalui bangunan. Karrholm dalam penelitiannya terhadap pedestrian di beberapa kota di Swedia seperti Skåne, Lund, Helsingborg dan Kristianstad, menyatakan bahwa sejak tahun 1990an kriteria sebuah lokasi dengan kemudahan akses serta sesuatu yang menarik menjadi tolok ukur keberhasilan sebuah ruang pejalan kaki [16]. Hal tersebut membentuk sebuah persepsi terhadap suatu daerah atau perkotaan yang di dalam Ilmu Manajemen persepsi tersebut diartikan sebagai sebuah "citra" dan citra itu yang pada akhirnya menyatakan sebuah identitas. Di dalam konsep Brand, identitas menjadi penanda yang dapat direpresentasikan melalui nama, logo, lambang, simbol, kata, atau penanda lainnya (lihat gambar 1).

Jika dilihat di dalam konteks perancangan Arsitektur, atmosfer lingkungan yang didesain dengan mempertimbangkan aspek kenyamanan yang "tepat guna" menjadi pendukung sebuah proses branding. Pada lingkungan pusat perbelanjaan misalnya, membangun atmosfer menjadi sangat penting karena aktivitas berbelanja merupakan salah satu daya tarik global dalam aspek wisata belanja. Hal inilah yang membuat peran arsitek di bidang komersial menjadi cukup penting karena banyak dan rumitnya konteks yang harus dipertimbangkan untuk tujuan branding [16].
Dalam ilmu Manajemen, Brand merupakan representasi dari pemegang kepentingan atau kekuasaan pada perusahaan atau pribadi terhadap nilai-nilai pokok seperti cita-cita, harapan, dan penggambaran diri. Nilai-nilai pokok menjadi sebuah visi yang menentukan pengembangan sebuah "Brand City" termasuk cara pengembangannya yang dapat diturunkan kepada para pendukungnya seperti staf, produk, customer sehingga terbentuk sebuah positioning terhadap sebuah "brand". Kuat tidaknya sebuah positioning ditentukan oleh proses dan cara penyampaian nilai-nilai pokok sehingga diperlukan sebuah proses managemen perencanaan dan perancangan yang tepat [17].

Pada konteks perdagangan dan bangunan komersial, hal yang paling mendasar dalam membangun positioning sebuah Brand Identity yakni merepresentasikan informasi produk tersebut melalui media pendukung, desain dan perancangan bangunan adalah salah satu medianya. Ada konsistensi yang perlu dibangun antara produk dan wadah (bangunan) sehingga terbentuk sebuah citra merek, dan konsistensi ini merupakan bagian dari aktivitas branding. Proses branding membutuhkan keterlibatan peran selebriti, peran arsitek, dan peran media [12].

Pada konteks yang lebih luas, sebuah bangunan dan ruang publik dapat menjadi sebuah "Brand City" dengan memanfaatkan media massa dalam memperkenalkan identitas sebuah kota atau lokasi atau Negara berdasarkan aspek sejarah, budaya, dan aspek sosial. [13]. Hal ini dapat dikaitkan dengan konsep Kevin Lynch (1960) tentang "landmark" sebagai salah satu elemen fisik dalam membentuk "City Image". Landmark menjadi salah satu elemen fisik yang perlu dipertimbangkan sebagai pengenalan terhadap sebuah perkotaan karena sifatnya yang "identifiable" melalui bentuk yang jelas, kontras dan kontekstual sesuai dengan keunggulan dari lokasi spasial sebuah perkotaan.

\section{BRANDSCAPE SEBAGAI METODE PEMBENTUKAN CITRA SEBUAH BRAND DALAM ARSITEKTUR}

Apabila di dalam Arsitektur kita mengenal proses Analisis yang menghasilkan zona-zona kebutuhan perancangan, maka di dalam konsep brand proses analisis tersebut dikenal sebagai brandscape. Melalui pemetaan persepsi umum masyarakat, persepsi khusus penggunanya, dan tanggapan isu Global, sebuah brand dapat meningkatkan nilai atau value agar dapat dikenal dan bermanfaat bagi sasaran 
yang ditujunya. Dalam hal ini, Arsitektur hadir sebagai media representasi yang menjaga konsistensi antara nilai sebuah brand dengan desain arsitektural yang mampu membentuk identitas citra sebuah brand.

Sebagai contoh, Pengalaman meruang seseorang terhadap sebuah tempat dipengaruhi oleh aktivitas, termasuk aspek-aspek seperti accessibility, attractivity, dan amenities menjadi faktor yang dapat membentuk persepsi seseorang terhadap sebuah tempat [18]. Seseorang akan berupaya menstrukturkan pengalaman meruang tersebut, lalu memahami, dan kemudian memberi makna terhadap sebuah tempat, lebih jauh lagi seseorang kemudian mampu membentuk atau bahkan mengubah sebuah tempat tersebut.

Sebuah karya secara arsitektural baik dalam skala kecil (bangunan) maupun skala besar (kawasan) mampu menjadi cerminan sebuah citra yang sejalan dengan desain, penampilan fisik, serta peruntukannya. Dalam Arsitektur Komersial di bidang retail misalnya, sebuah identitas mampu dikomunikasikan melalui pengalaman meruang internal dan eksternal [12] p432. Dalam konteks perkotaan, sebuah citra kota atau wilayah atau kawasan dipengaruhi oleh peta mental seseorang terhadap kota tersebut [3]. Peta mental ini merupakan bagian dari pengalaman meruang seseorang yang juga dipengaruhi pula oleh faktor lingkungan dan budaya sehingga setiap orang akan memiliki peta mental yang berbeda-beda walaupun di lingkungan yang sama.

Pencitraan sebuah kota, bangunan, atau lingkungan dapat dipengaruhi oleh komponen-komponen kecil yang menonjol, misalnya seperti unsur simbolik. Peta mental dapat dibedakan dalam 2 bagian, peta mental menurut penduduk kota dan peta mental menurut pengunjung, perbedaannya terletak pada tingkat interaksi yang dimiliki oleh keduanya [3] p.34. Apabila dibandingkan dengan makna Brand dan Image, maka peta mental dapat menjadi tujuan utama (goal) sebuah creator untuk menciptakan "strong brand". "Peta mental menurut penduduk" dapat diilustrasikan sebagai sebuah brand dan "Peta mental menurut pengunjung" dapat dikatakan sebagai sebuah Image. Jika perbedaannya terletak pada interaksi, maka dalam gol sebuah creator adalah mencari irisan dari perbedaan tersebut untuk membentuk sebuah "strong brand".

\section{KONSEP DIGITAL DI DALAM ARSITEKTUR DAN BRAND}

Di dalam Arsitektur dan Brand, teknologi digital hadir sebagai alat pendukung yang mampu menguraikan kebutuhan perancangan berdasarkan data kolektif yang ada. Dengan kata lain, analisis dan perancangan yang didukung secara digital dapat dilakukan sesuai dengan input data yang dilakukan. Selain itu konsep digital membentuk sebuah sistem perancangan yang mengutamakan pengguna sebagai dasar perancangannya. Cloud dan Interkoneksi Data menjadi wadah dalam pengumpulan data untuk diolah dan menemukan dasar kebutuhan yang berfungsi sebagai material perancangan arsitektur.

Pengolahan data secara digital dapat memanfaatkan data cloud yang memuat data perilaku seseorang dalam mengakses internet. Dari data perilaku ini, kita dapat mengetahui trend kebutuhan saat ini. Selain itu, data-data online berbasis pengguna yang saat ini menjadi kebutuhan gaya hidup masa kini seperti media-media sosial dapat dikumpulkan untuk melihat trend kebutuhan.

Media-media yang digunakan dalam mencari dan mengumpulkan data tersebut berasal dari platform online yang data algoritmanya dapat dibaca dan petakan. Paling umum, media ini kita kenal sebagai media social, search engine, youtube, perdagangan online atau e-commerce, berita online atau online news. Setiap data dikumpulkan dan dibaca serta dianalisis untuk mencari nilai-nilai apa yang berguna dalam meningkatkan value sebuah brand.

\section{UNSUR-UNSUR PENTING DALAM PERANCANGAN ARSITEKTUR, BRAND, DAN TEKNOLOGI DIGITAL}

Melalui pembahasan sebelumnya, terangkum beberapa unsur penting yang saling melengkapi di dalam aspek perancangan arsitektur yang berhubungan dengan konsep brand dan Teknologi dan disusun tanpa meniadakan aspek dasar dalam perancangan arsitektur.

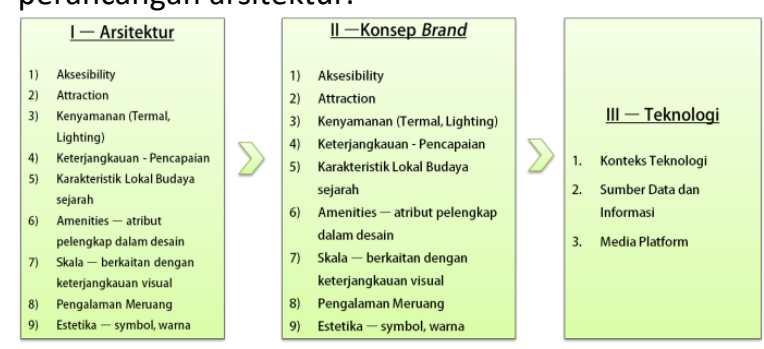

Gambar 4 Rangkuman Komponen Teori Perancangan Arsitektur, Konsep Brand dan Teknologi 
Sumber Ilustrasi : Peneliti, 2020

Apabila dilihat dari ilustrasi Gambar 4, beberapa komponen atau aspek yang sama-sama perlu dipertimbangkan antara lain:

1. User atau Pengguna. Asal dan Tujuan dari proses perancangan Arsitektur, pengembangan sebuah brand, serta pengumpulan data secara Digital dilakukan berdasarkan penggunanya. Di dalam Arsitektur, Pengguna menjadi tujuan utama sebuah perancangan karena karya tersebut didesain untuk mewadahi aktivitas penggunanya. Latarbelakang, kebiasaan, kebutuhan, karakteristik dan aktivitas menjadi poin-poin penting di dalam komponen pengguna. Di dalam konsep brand, "pengguna" biasa disebut dengan "customer". Customer menjadi kunci utama sebuah brand dibentuk dan dikembangkan. Demikianpula dengan konteks Digital. Metode analisis dan pengumpulan data secara digital dimulai dari user activity atau user decision [19].

2. Attraction atau Atraksi. Atraksi ini berkaitan dengan "apa yang dilihat" dan "apa yang dilakukan" [20]. Dalam Arsitektur, Atraksi ini berkaitan dengan sesuatu yang unik dan menghibur. Kondisi ini paling umum dapat kita temui pada konteks destinasi wisata. Di dalam konsep Brand, sesuatu yang dilihat dan ingin dilakukan lebih bersifat transaksional baik yang sifatnya jual-beli maupun di luar lingkup bisnis [21]. Apabila dalam konteks Digital, sebuah atraksi berkaitan erat dengan channel-channel yang berhubungan dengan pemasaran dan pertunjukkan melalui platform berbasis online yang dapat mengarahkan atau menarik perhatian penggunanya dalam mengambil keputusan dalam mengakses dan atau melakukan transaksi [15].

3. Kenyamanan. Di dalam Arsitektur dapat kita kenal dengan istilah "atmosfer" atau suasana yang mendukung kegiatan penggunanya. Paling sering kita jumpai dalam proses perancangan ruang publik komersial, seperti resto, café, ruang baca, museum, pusat perbelanjaan, dan ruang publik lainnya. Tentu di dalam konteks Brand, kenyamanan menjadi salah satu indikator penting yang mampu memengaruhi keputusan customer_atau targetnya dalam menaruh kepercayaan terhadap sebuah brand [22]. Dalam konteks Digital, segala sesuatu yang menimbulkan rasa kepercayaan (brand trust dan brand awareness) mampu difasilitasi melalui proses digital untuk selanjutnya membentuk persepsi citra [23]. Hal ini sebetulnya memiliki benang merah yang cukup kontras karena kenyamanan adalah suatu indikator turunan dari komponen user, ketika komponen user dianalisis, sudah tentu faktor kenyamanan menjadi hal utama yang perlu diuraikan. Bagamana pengguna menghabiskan waktunya, media online apa yang sering pengguna akses, jenis media yang bagaimana yang sering pengguna gunakan, di mana lokasi yang sering pengguna lalui (melalui data Google map misalnya) dan lain sebagainya. Datadata tersebut dapat dikumpulkan dan dianalisis melalui bantuan digital [24].

4. Lokasi. Di dalam Arsitektur, komponen ini tidak kalah pentingnya, karena merupakan tempat sebuah karya akan terbangun. Secara digital, sebuah "tempat/ lokasi" dapat dilihat dari askes data lokasi yang sangat erat kaitannya dengan konteks sejarah dan latarbelakang sebuah lokasi. Hal ini tentu menjadikan proses branding menjadi sangat "kaya" makna karena menyangkut kehidupan sosial masyarakat. Melalui lokasi, sebuah tren dapat dideteksi dengan sangat mudah dan hal ini sangat membantu proses perancangan dan proses branding.

Selain ke empat komponen tersebut, ada banyak aspek atau elemen perancangan di dalam Arsitektur yang mampu menjadi pendukung atau turunan dari 3 komponen yang sudah terurai. Misal, elemen pencahayaan, penghawaan, keterjangkauan visual, skala dan atribut visual yang dapat mendukung komponen atraksi dan kenyamanan dari penggunanya. Dengan kata lain, aspek perancangan di dalam arsitektur dan konsep perancangan dan analisis secara digital dapat digunakan untuk menguraikan kebutuhan dalam proses pengembangan dan pembentukkan sebuah brand.

\section{KESIMPULAN}

Kehadiran ilmu pengetahuan teknologi yang disertai dengan kecerdasan buatan menjadi sebuah percepatan informasi antara pemberi info dan penerima. Teknologi digital menjadi hal penting 
dalam mendukung proses perancangan arsitektur karena sifatnya yang akurat dan tepat. Informasi yang berupa data, secara digital dapat dianalisis untuk menghasilkan strategi pengembangan terhadap sebuah brand melalui perancangan arsitektural yang menarik, bermanfaat, dan diterima sesuai dengan kebutuhan penggunanya. Selain pengguna, pengembangan informasi data dengan memanfaatkan media digital berpatokan pada sebuah landasan Spirit, rasa Bangga dan Cita-Cita. Meski erat kaitannya dengan dunia marketing dan bisnis, namun tidak bisa dipungkiri bahwa sistem saluran informasi perlu melibatkan keilmuan marketing untuk mendukung proses branding dalam konteks arsitektur.

Aspek "Pengguna" menjadi hal utama dalam proses merancang baik dalam hal arsitektur, proses branding, maupun proses analisis perancangan digital. Kemudian aspek yang mampu memengaruhi keputusan pengguna dapat ditangkap sebagai sebuah kesempatan dalam merancang sebuah desain, hal ini tentu dapat dilakukan dengan bantuan teknik analisis dan pengumpulan data secara digital melalui media platform yang ada.

Selain itu aspek Kenyamanan juga termasuk hal penting dalam merancang sebuah karya yang bermanfaat bagi penggunanya. Kenyamanan di dalam konsep brand berkaitan erat dengan model perancangan pencahayaan dan termal, struktur yang bersifat global adalah issue terkini dunia yang ingin disesuaikan dengan desain bangunan "kekinian". Keterjangkauan visual di dalam konsep brand juga dapat dijawab dengan teori Pencapaian dan rotasi penglihatan, simbol pada konsep brand erat hubungannya dengan konteks lokal budaya sejarah melalui warna, gubahan bentuk, garis dan lainnya. Dengan demikian dapat dikatakan teori konsep brand dan teori perancangan arsitektur dapat saling bergandengan. Teori arsitektur dapat menjadi akar dasar yang dipegang untuk mengembangkan sebuah brand sehingga karya desain perancangan bangunan tidak kehilangan jangkar akarnya, dan tetap bermuara pada disiplin ilmu arsitektur.

Brand dapat didefinisikan sebagai sebuah janji, komunikasi dan citra. Arsitektur mampu menjadi media dalam mengkomunikasikan identitas merek yang konsisten. Bagi desainer dan arsitek, konsep brand untuk sebuah bangunan mampu menghadirkan banyak peluang dalam menciptakan bentuk dan gaya yang khas. Fenomena pasar global akan turut mendorong perkotaan untuk mengembangkan destinasi wisatanya menjadikan sebuah kota untuk ber-regenerasi dan akan terus menawarkan peluang untuk bangunan baru yang ikonik.

Selain itu lokasi, dan sejarah memberikan pecahanpecahan diferensiasi dan berkontribusi pada kesadaran dan reputasi dari sebuah brand hingga sebuah perkotaan dalam konteks yang lebih luas.

Popularitas media digital berbasis internet juga berpeluang dalam mengambil peran penting dalam konsep brand karena sifatnya yang tidak memiliki kesenjangan antara penyedia dengan penggunanya. Dengan berkembangnya teknik komunikasi yang kreatif, dan berkelanjutan, media digital mampu menyampaikan sebuah "pesan" dua arah sehingga terbangun sebuah kepercayaan.

\section{PENUTUP}

Sebagai penutup. penulisan ini ingin menyampaikan bahwa Perancangan Arsitektur, konsep Brand, dan Teknologi Digital dapat membuat sebuah objek hadir tidak hanya untuk tujuan keuntungan saja melainkan sebagai entitas dari budaya. Karya dan Brand yang kuat adalah yang mampu dihasilkan melalui proses perancangan yang memperhatikan etika.

Dengan demikian, esensi dasar perancangan Arsitektur tidak dapat hilang meski berbaur dengan disiplin ilmu Manajemen karena baik dalam ilmu Manajemen maupun Arsitektur bahkan Teknologi Digital selalu memperhatikan penggunanya. Bahkan, keterlibatan Perancangan Arsitekur mampu membuat konsep brand menjadi lebih kuat karena dalam proses perancangan arsitektur, selalu memperhatikan sisi etika, karakteristik lokal dan berbudaya, sehingga setiap karya lahir lebih orisinil, tepat manfaat (berdaya guna tinggi) dan berbudaya. Arsitektur tidak akan kehilangan jangkar akar perancangannya meski berkolaborasi dengan banyak ilmu karena muaranya berasal dari pengguna.

\section{PUSTAKA}

[1] J. R. Saura, 'Using Data Sciences in Digital Marketing: Framework, methods, and performance metrics', Journal of Innovation and Knowledge, 2020, doi: 10.1016/j.jik.2020.08.001.

[2] F. D. K. Ching, Architecture : Form Space and Order, 3rd ed. John Wiley \& Sons Ltd, 2007. 
[3] Setiawan and B. Haryadi, Arsitektur, Lingkungan dan Perilaku, I., no. Arsitektur, Sains \& Teknologi. Gadjah Mada University Press, 2010.

[4] N. Spiller, 'Plectic architecture: towards a theory of the post-digital in architecture', Technoetic Arts, vol. 7, no. 2, pp. 95-104, 2009, doi: 10.1386/tear.7.2.95/1.

[5] D. B. Susanty and G. Sukowiyono, 'Hunian Masyarakat Di Dataran Tinggi', in Semnas Infrastruktur Berkelanjutan 2019 Era Revolusi Industri 4.0, 2019, pp. 63-68.

[6] Y. D. Ekaputra and M. M. Sudarwani, 'Karakter Fisik dan Non Flsik Dusun Mantran Wetan Kabupaten Malang', sEMARANG, 2014.

[7] N. Morgan, A. Pritchard, and R. Pride, Destination Brands 'Managing Place Reputation', 3rd Editio. Oxford, UK: Elsevier Ltd., 2011.

[8] J. E. Schroeder and M. S. Morling, Brand Culture. London: Routledge, Taylor \& Francis Group, 2006.

[9] F. G. Mariutti and J. de M. E. Giraldi, 'Country Brand Identity: An Exploratory Study about the Brazil Brand with American Travel Agencies', Tourism Planning and Development, vol. 11, no. 1, pp. 13-26, 2014, doi: 10.1080/21568316.2013.839469.

[10] N. V Golik and A. I. Izvekov, 'Modern Business Philosophy : Brand as a Phenomenon', no. January 2018, 2019.

[11] P. Kotler and K. L. Keller, MARKETING MANAGEMENT 14E, 14th ed. New Jersey: Pearson Education, Inc., publishing, 2012.

[12] A. E. Kirby and A. M. Kent, 'Architecture as brand: Store design and brand identity', Journal of Product and Brand Management, vol. 19, no. 6, pp. 432-439, 2010, doi: 10.1108/10610421011085749.

[13] M. Ristic, Architecture, urban space and war : the destruction and reconstruction of Sarajevo. 2018.

[14] N. Verina and J. Titko, 'Digital transformation : conceptual framework', no. August, 2019, doi: 10.3846/cibmee.2019.073.

[15] P. K. Kannan and H. Alice, 'Digital marketing : A framework, review and research agenda Digital marketing : A framework, review and research agenda', International Journal of Research in Marketing, vol. 34, no. 1, pp. 2245, 2017, doi: 10.1016/j.ijresmar.2016.11.006.

[16] M. Kärrholm, Retailising Space - Architecture, Retail and the Territorialisation of Public

Space, Mix Articl. Sweden: Ashgate Publishing Limited, 2012.

[17] R. K. Srivastava, 'Understanding brand identity confusion', Marketing Intelligence \& Planning, vol. 29, no. 4, pp. 340-352, 2011, doi: $10.1108 / 02634501111138527$.

[18] R. Mirsa, Elemen Tata ruang Kota. Yogyakarta: Graha Ilmu, 2011.

[19] F. Pramanawati and S. R. T. Astuti, 'Analisis Pengaruh Brand Image Dan Perceived Usefulness Terhadap Repurchase Decision Browser Mozilla Firefox Dengan Brand Attitude Sebagai Variabel Intervening', Diponegoro Journal Of Management, vol. 6, no. 1, pp. 1-12, 2016.

[20] M. Y. F. Salasa and T. Ismail, 'Analisis Pengaruh Attraction, Accessibility, Amenities, dan Ancillary Terhadap Kepuasan Wisatawan Pantai Tiga Warna Malang', Jurnal IImiah FEB, vol. 7, no. 1, pp. 1-8, 2018.

[21] A. Lukitaningsih, 'Perkembangan Konsep Pemasaran: Implementasi dan Implikasinya', Jurnal Maksipreneur: Manajemen, Koperasi, dan Entrepreneurship, vol. 3, no. 1, p. 21, 2013, doi: 10.30588/jmp.v3i1.85.

[22] Y. S. Kusuma, 'Pengaruh Brand Experience Terhadap Brand Loyalty Melalui Brand Satisfaction Dan Brand Trust Harley Davidson Di Surabaya', Jurnal Manajemen Pemasaran Petra, vol. 2, no. 1, pp. 1-11, 2014.

[23] H. Noma and J. Crossman, 'Analogue and digital mindsets: Some implications for intercultural communication between Western and Eastern organisations', Asian Academy of Management Journal, vol. 17, no. 1, pp. 115-129, 2012.

[24] A. Rachman, 'Analysis of Effect of Physical Evidence and Service Assurance on Customer Satisfaction and Customer Loyalty in using Car Rental Service (PT Pusaka Prima Transport Cases)', IOP Conf. Series : Materials Science and Engineering, vol. 755, no. 1 , 2017, doi: 10.1088/17426596/755/1/011001. 